\title{
Key Determinants of Repurchase Intention toward Organic Cosmetics
}

\author{
Phuong Ngoc Duy NGUYEN ${ }^{1}$, Vinh Tan NGUYEN ${ }^{2}$, Nguyen Ngoc Thao VO $^{3}$ \\ Received: April 25, 2019 Revised: June 27, 2019 Accepted: July 1, 2019
}

\begin{abstract}
This paper aims to discover factors and their influences degree to repurchase organic cosmetic in Vietnam. In addition, this research also discloses the main segments that have high demand re-buying intention based on demographic groups of gender, age, income, educational level, job, type of products, and place of production. Twenty-eight scale was designed based on previous studies and adjusted to match the 5-point Likert scale to conduct measurement. By using survey method to test hypotheses and set up conceptual models to collect 295 Vietnamese consumers who have experience in consuming organic cosmetic by explain the results through Smart PLS software. The findings show that there is positive attitude of customers to the intention of acquiring organic cosmetics, green perceived and customer satisfaction. In addition, customer satisfaction, knowledge of products, safety values, and environmental protection consciousness also play important roles to form a positive attitude of customers for products. Moreover, the consciousness of green living of consumers accounts for a high proportion in creating customer satisfaction for organic products. The results show useful information for current premises to determine the factors that influence the decision to repurchase organic cosmetic product, that provide business strategies.
\end{abstract}

Keywords: Organic Cosmetic, Repurchase Intention, Attitude, Customer Satisfaction.

JEL Classification Code: M30, M31, M37.

\section{Introduction}

On the demand side, customers have more positive sight with the organic product than others, due to being healthier (Beharrel \& MacFie, 1991). The statistic described that the consumption degree on organic products remarkably went up (Verhoef, 2005). For instance, the German collected the revenue from selling the green staples about $€ 2.05$ billion in 2000 , compared with that figure in 2004 , grew up to $€ 3.5$ billion. Furthermore, organic products stably developed in

1 First Author and Corresponding Author. Deputy Manager, Office of Research and Development, School of Business, International University - VNUHCM, Vietnam. [Postal Address: Quarter 6, Linh Trung Ward, Thu Duc District, Ho Chi Minh City, 700000, Vietnam]. Email: nndphuong@hcmiu.edu.vn

2 Vice Director, Academy of Politics Region II, Vietnam. Email: vinhnguyenktpt@gmail.com

3 Research Assistant, School of Business, International University VNUHCM. Email: vongocthaonguyen510@gmail.com

(๑) Copyright: Korean Distribution Science Association (KODISA)

This is an Open Access article distributed under the terms of the Creative Commons Attribution NonCommercial License (https://creativecommons.org/licenses/by-nc/4.0/) which permits unrestricted noncommercial use, distribution, and reproduction in any medium, provided the original work is properly cited.
2014 by $7.4 \%$, the sale volume of organic products soared from $€ 22.4$ to $€ 47.4-$ about $110 \%$ (IFOAM-EU, 2016). Besides the organic cosmetic also have significant consumption in America, Australia, and EU. The market showed that the sale volume of organic cosmetic in the United States was achieved about $\$ 700$ million in 2015 , and this figure will be able to increase to $\$ 1.650$ million in the next ten-year period.

According to Luu (2017), about $80 \%$ citizens buy at least one cosmetic product in year, in that one fourth of the cost of personal care is spent on beauty products. Specially, the demand for green cosmetics is on the rise. Vietnamese and French women have same demand to use the organic products- consumption degree fluctuates from $20-50 \%$. Therefore, human have a trend to purchase and using the natural and organic products, such as food, article of daily necessity, personal care products. Because they interested in not only enhance appearance but also maintain healthy.

Almost previous researchers focus on the customer willing to buy organic cosmetic products in the developed and developing countries context, such as in USA (Kim \& Seock, 2009; Kim \& Chung, 2011), in Greece (Tsakiridou, Boutsouki, Zotos, \& Mattas, 2008), in Malaysia (Abd 
Rahman, Asrarhaghighi, \& Ab Rahman, 2015), in India (Pudaruth, Juwaheer, \& Seewoo, 2015) and in Vietnam (Nguyen, 2014; Nguyen \& Nguyen, 2017). While there is a little study re-buying behavior of customer toward organic cosmetics (Ghazali, Soon, Mutum, \& Nguyen, 2017). Therefore, some of the outcomes from the previous research that is able to apply factors to research this study. The researchers conduct this study to observe Vietnamese consumers' establishment to repurchasing organic cosmetic and analyze main determinants on attitude toward repurchasing organic cosmetic and customer satisfaction. Besides that, it is essential to investigate correlation among attitude, customer satisfaction, green perceived value, and repurchase intention. The results of the study expect to provide useful information about the attitude towards repurchasing toward organic cosmetic products, identify the level of significance of these factors and help manager to propose managerial implications to enhance customer repurchase intention organic products.

\section{Conceptual Framework and Hypotheses Development}

In this section, related theories and previous studies have been discussed to identify key determinants influence on repurchasing intention organic cosmetic products.

\subsection{Health Consciousness, Environmental Concern, Product Knowledge, Safety Value, Satisfaction, and Attitude toward Repurchasing Organic Cosmetic Products}

Health consciousness evaluates about the prepared degree in participating healthy actions (Becker, Haefner, Kasl, Kirscht, Maiman, \& Rosenstock, 1977). In previous research, the interest of health is the principle motivations encourage purchase green yields (Lockie, Lyons, Lawrence, \& Mummery, 2002). Health concern customers have high level in conscious and care about enhancing and sustaining their fitness and standard life, such as precluding illness by self-awareness of health and participating healthy behavior (Gould, 1988; Newsom, McFarland, Kaplan, Huguet, \& Zani, 2005). This factor is determined a notable elements effect to the user's attitude toward organic products (Paksoy, Özçalici, \& Çelikkan, 2014; Yadav \& Pathak, 2016). In the buying personal care products, human who have high knowledge about healthy value willing to pay more money for cosmetic products that make from natural, and/or cosmetic ingredients (Johri \& Sahasakmontri, 1998). Health concern is self-awareness about nutrition system and health
(Kraft \&Goodell, 1993), create a confident impact on buying organic yields (Lockie et al., 2002). In the cosmetic case, the customers who have high health concern will consider about the safety of product with skin, therefore they spent more focus on the benign ingredients of product than the other (Johri \& Sahasakmontri, 1998). In the model of Ghazali (2017), health consciousness is one of factors impact to the attitude repurchasing intention toward organic personal care products. Hence, health consciousness has positive effect on consumer attitudes toward purchasing and repurchasing organic cosmetic products. The first hypothesis proposed as follows:

\section{Hypothesis 1: Heath consciousness positively affect to the consumer attitude toward repurchasing organic cosmetic products.}

Chan and colleagues (2000) define environmental concern is the individual feeling level toward environmental issue, they tend to pay more attention to ingredient of products and produce process. Organic cosmetic is as seen as eco-friendly products due to non-toxic and easy decomposable (Van Loo, Diem, Pieniak, \& Verbeke, 2013). Therefore, the environmental concern is seen as a primary step in developing organic consumption. Due to the ecofriendly products, process of producing organic cosmetics is operated without animal testing, chemical toxic, and synthetic chemicals (Prothero \& McDonagh, 1992). The environmental attention is a basic step leading to purchase organic products for the environmental protection purpose (Dembkowski, 1998; Smith \& Paladino, 2010). The previous research of Kim and Chung (2011), Smith and Paladino (2010), Yadav and Pathak (2016), the green products are conveniently consumed by customers who have high environmental consciousness. Later, Ghazali (2017), environmental concern is one of factors impact to the attitude repurchasing intention toward organic personal care products. Therefore, environmental concern positive impact on consumer attitudes toward purchasing and repurchasing organic cosmetic products. In sum, it is hypothesized that:

\section{Hypothesis 2: Environmental concern positive effect to the consumer attitude toward repurchasing organic cosmetic products.}

Knowledge is significant key leading to customer purchase decision, especially applying in organic products (Hill \& Lynchehaun, 2002). If the customers haven't knowledge about information or high experience degree about the organic products' benefit, they will not buy its (Chryssochoidis, 2000). With some customers who have high level of education, they often want to find the way to 
growing organic product and have high positive attitude with this figure (Smith \& Paladino, 2010; Nguyen, 2015) and being more able to consume the green yields (Wandel \& Bugge, 1997). Furthermore, the knowledge about organic have high impact to the attitude repurchase intention toward organic or natural personal care products (Ghazali et al., 2017). Therefore, product knowledge positively effects on consumer's attitude toward purchasing and repurchasing organic cosmetic products. After recapitulating the previous studies, the following hypothesis has been proposed:

Hypothesis 3: Product knowledge positive effect to the consumer attitude toward repurchasing organic cosmetic products.

Food hygiene and safety is one of the top problems in the modern social, hence, human tend to use organic food because healthy protection demands. In the previous study, above $50 \%$ customer buy the organic products in the first time because of non-chemical ingredient (Yin, Wu, Du, \& Chen, 2010). Applying to the cosmetic case, human have high risk of cancer, respiratory disorders, and so on due to chemical ingredients such as paraben, lead, and others toxic elements. Besides, this figure is recognized far away non-toxic and chemistry ingredient that is made from origin plants and herbs. Safety consciousness is one of the reasons that stimulate consumer's positive attitude toward organic produce (Nguyen, 2015; Paksoy et al., 2014). This figure is also helpful to boost the consumer attitude toward repurchasing organic or natural personal care products (Ghazali et al., 2017). Therefore, safety value has optimistic influence on consumer's attitude toward purchasing and repurchasing organic cosmetic products. The discussion of previous studies leads us to the following hypothesis:

Hypothesis 4: Safety value positive effect to the consumer attitude toward repurchasing organic cosmetic products.

According to the role of satisfaction in a customer behavior model, the satisfaction directly impacts to the attitude (Oliver, 1980). It is argued that the satisfaction has significant influence on attitude degrees, which in turn influences customer's intention. Besides previous studies demonstrated the positive relationship between satisfaction and attitude (Sivadas \& Baker-Prewitt, 2000; Davis \& Heneike, 1994). In the case of repurchasing, the customer satisfaction also has high impact on customer attitude toward repurchase intention (Koelemeijer, 1993). From those background, it is suggested that:
Hypothesis 5: Customer satisfaction positive effect to the attitude toward repurchasing organic cosmetic products.

According to Fishbein and Ajzen (1980), people often attend to an action when they have positive attitude with this action. Therefore, the previous studies of Van Loo et al. (2013) and Kim and Chung (2011) showed that customer who have high attitude with any product is easily purchase it. Amount of successful research about positive correlation between attitude and intention in consuming organic products (Smith \& Paladino, 2010) such as green hotel (Han \& Kim, 2010); organic yogurt (Van Loo et al., 2013); organic skin/hair care products (Kim \& Chung, 2011). In the repurchase case, the attitude has a significant role that leading to the consumer repurchase intentions, which has been confirmed based on studies about the re-buying Korean cosmetic of Thailand (Wangwiboolkij, 2012) and organic personal care product in Malaysia (Ghazali et al., 2017). In sum, the research proposes the following hypothesis:

Hypothesis 6: Attitude toward repurchasing organic cosmetic product positive effect to the consumer repurchases intention.

\subsection{Green Perceived Value, Customer Satisfaction and Attitude toward Repurchasing Organic Cosmetic Products}

Perceived value is a general customer's assessment of the benefits received and the payment value of a product. Previous studies of Cronin, Brady, and Hult (2000); Keh and Sun, (2008) recognize an optimistic relationship between perceived value and customer satisfaction. Following to this theory, Chen and Chang (2012) determine the green perceived value (GPV) is perceived value that is establish based on an environmentally friendly expectation of customer. Numerous previous studies of Chen (2013); Lam, Lau, and Cheung (2016); and Sun, Chang, and Huang (2016) set up a sanguineous correlation between GPV and the customer's pleasing. Therefore, the green perceived value positive impact to the customer satisfaction. Therefore, seventh hypothesis is established as follows:

\section{Hypothesis 7: Green perceived value positive effect to the customer satisfaction.}

Customer satisfaction is the result of comparison between anticipation and real indication after the trial period (Tse \& Wilton, 1988). Hence, it easily understands when relate the 
satisfaction with the repurchase intention. Numerous previous researches of Bolton (1998), Cronin and Taylor (1992), and so on that supported to the positive relationship between them. This is the main factor leading to customer re-buying intention (Sharma \& Patterson, 2000). According to the previous studies of Sun et al. (2016) and Nguyen (2015), the customer who is more satisfaction with a beauty product will tend high degree to pay money for this cosmetic product again. Lam et al. (2016) research the influence rate of satisfaction on repurchase intention toward green products. These study shows that the customer satisfaction has positive development with the green repurchase intention. Therefore, the study is to determine that the customer satisfaction is positive influence with the repurchase intention toward organic cosmetic products. The discussion of previous studies leads us to the following hypothesis:

Hypothesis 8: Customer satisfaction positive effect to the attitude toward repurchasing organic cosmetic products.

\subsection{Green Perceived Value and Repurchase Intention}

In 2010, Zhuang, Cumiskey, Xiao, and Alford (2010) determined that perceived value plays an essential role in buying intention. This is consistent with the Sweeney and Soutar (2001) evidence, if the perceived value is low, purchase intention will be decreased. This element help customer post-purchase behavior to positively ratio develops (Tam, 2004). Moreover, based on the demand for green products and environment protection, Chen and Chang (2012) create a research to confirm the optimistic linking between green perceived values and willing to pay green products. In 2013, Chen made another study to find out the positive connection between the value of green awareness value and the loyalty. Hence, the research recognize that green perceived value has high positively influence on green repurchase intention, in accordance with result of Lam (2016). Applying the previous results for this study, it is to confirm that green perceived value directly optimistic influence on organic cosmetic repurchase intention. In sum, the research proposes the final hypothesis, following:

Hypothesis 9: Green perceived value positive effects to the consumer repurchase intention toward organic cosmetic products.

\section{Research Methodology}

\subsection{Operationalization of Constructs}

The employ employed previous studies to conduct measurements for different structures and reconfirmed for this model. Most of the previous measurement models were designed based on 5-point Likert scale to conduct measurement, with the principle of from the lowest level (1) "strongly disagree" to highest level (5) "strongly agree.". First, the measurement of health consciousness is created with seven items by mixing and designing based on the previous studies of Michaelidou and Hassan (2008), Lea and Worsley (2005), and Bauer, Heinrich, and Schäfer (2013). Second, the five-item construct for the environmental concern is also synthesized and adjusted based on the articles of Lindeman and Vaananen (2000), Lea and Worsley (2005), and Bauer et al. (2013). Product knowledge is significant key leading to customer purchase decision, especially applying in organic products (Hill \& Lynchehaun, 2002). Furthermore, the factor applies the four-item measurement designed from Bauer et al. (2013) study to investigate the safety value. Exploring the consumer's attitude toward repurchase intention organic cosmetic throughout the measurement scale five-item that are created based on Bansal and Taylor (2002) research. Next, customer satisfaction is defined as the result of comparison between anticipation and real indication after the trial period (Tse \& Wilton, 1988), which is measured by four items in the Oliver (1996) study. Moreover, the five-item measurement scale of green perceived value is adapted from the research of Patterson and Spreng (1997). Finally, the repurchase intention construct is seen as the willing to buy a product or brand again of user, which has eight items designed from studies of Davidow (2003), and Bredahl (2001).

\subsection{Survey Administration and Sample}

The study applied a survey method to test hypotheses and conceptual models. This study considers Vietnamese people to be consumers of organic cosmetics and has at least one experience of using products at all. Google form data collection is also applied. This is an effective method to save time, data storage and ensure privacy. The questionnaires were delivered into cosmetic sales pages (Facebook, Instagram, Zalo) as well as personal mail messages. Besides, the hardcopy questionnaire was also distributed in schools as well as organic cosmetics stores in HCMC area. After the survey process, 320 actual 
announcements were dispensed with 295 replies, representing a return rate of $92.18 \%$.

Among the respondents, of which 250 are female (about $85 \%$ ), and the remaining $15 \%$ are male. The result shows that the most population age from 18 to 29 with 200 consumers, which occupied for $68 \%$. Following, the age ranging from 30 to 45 that account about $22 \%$, while minor amount young consumers about $4 \%$. In terms of marital status, the single one weights for $62 \%$ and $34.6 \%$ for married one, respectively. However, most of them still have no children, it accounts for $56 \%$. Regarding respondents' job, the majority of them are students, office workers and specialist, and other segment respectively accounting for $43 \%, 32 \%$, 20\%, meanwhile, only $5 \%$ of retailers use products. About income, the target customers of organic cosmetics are spread out in 3 to 7 million (33\%), 7-15 million (28\%), and over 15 million (24\%), while, consumers with incomes below 3 million also account for a good rate of about $15 \%$. Furthermore, the customers who have used organic cosmetics mostly completed college or are in college, accounting for more than $70 \%$ of all respondents. More important, the product segment account for about $32 \%$ of the consumption of organic body care and $29 \%$ figure for organic skin care products. Finally, the consumption of US and French products accounts for $50 \%$ of the total survey, followed by $30 \%$ respectively divided by Russia, Vietnam, and Australia product.

\section{Results}

The aim of this study is to examine the relationship between predictors and online repurchase intention. The data was analyzed using PLS-SEM since it is suitable to analyze complicated structural model and identify predictors, according to Hair, Ringle, and Sarstedt (2011). PLS-SEM is considered to be appropriate for exploratory studies.

\subsection{Model Test}

To make certain the measurement model, applying PLS to appriciate the feature of all the scales that is participating in this study. Because of accomodating of reflective indicators, checking the reliability and validity of data is a fundamental and indispensable step in data analysis (Hair et al., 2014). Each value of the index are tested the suitable level to ensure the measurment of intended target. General, thirdteen objects were dropped from the measurement scale. in the detail, the researcher removed a number of items out of the scale due to break standard rules of factor loading including two items of health consciousness, two items of environmental concern, one of safe value, two items of attitude, two of satisfaction, and five items of repurchase intention. The measrement scale remains twenty-eight items for eight constructs. The indicator loadings are larger than 0.7 (Table 1), demonstrating convergent validity (Hair et al., 2013). The composite reliability of each facors in this model scale are greater than 0.4 , which be able to reinforce the feasibility of measurement (Hair et al., 2014). Followed by checking the average variance extracted (AVE) value of construct to measure the convergent validity of the model, the values that are shown in Table 1 range from 0.586 to 0.806- higher than the AVE ratio standard that is 0.5 , therefore, all eight-element suitable to certify convergent validity of model.

The discriminant validity was tested using the FornellLarcker criterion of model that is calculated by the SmartPLS software, indicators that are highlighted by researchers are similar connections (Table 2). Thus, it is easy to see that these indicators are larger than other indicators in the same column. Therefore, all items satisfy the above conditions, so the validity of discrimination can be said to be appropriate.

Table 1: Factor Loadings and Composite Reliability of the Measurement Model

\begin{tabular}{|c|c|c|c|}
\hline Constructs & Items & Factor Loadings & CR \\
\hline Health consciousness (HC) & 5 & $0.707-0.866$ & 0.889 \\
\hline Environmental concern (EV) & 3 & $0.719-0.825$ & 0.809 \\
\hline Product knowledge (PK) & 4 & $0.761-0.788$ & 0.880 \\
\hline Safety value (SV) & 3 & $0.866-0.918$ & 0.926 \\
\hline Attitude (ATR) & 3 & $0.754-0.911$ & 0.883 \\
\hline Consumer satisfaction (CS) & 3 & $0.739-0.9$ & 0.864 \\
\hline Green perceived value (GPV) & 4 & $0.732-0.823$ & 0.861 \\
\hline Repurchase intention (RI) & 3 & $0.6-0.901$ & 0.900 \\
\hline
\end{tabular}

Note: $\mathrm{CR}$ = Composite Reliability, AVE = Average Variance Extracted. 
Table 2: Result of the Discriminant Validity

\begin{tabular}{|c|c|c|c|c|c|c|c|c|}
\hline & ATR & CS & EV & GPV & HC & PK & RI & SV \\
\hline ATR & $\mathbf{0 . 8 4 6}$ & & & & & & & \\
\hline CS & 0.671 & $\mathbf{0 . 8 2 5}$ & & & & & & \\
\hline EV & 0.530 & 0.458 & $\mathbf{0 . 7 6 5}$ & & & & & \\
\hline GPV & 0.623 & 0.669 & 0.573 & $\mathbf{0 . 7 8 0}$ & & & & \\
\hline HC & 0.578 & 0.559 & 0.524 & 0.566 & $\mathbf{0 . 7 8 6}$ & & & \\
\hline PK & 0.553 & 0.541 & 0.373 & 0.540 & 0.474 & $\mathbf{0 . 8 0 5}$ & & \\
\hline RI & 0.601 & 0.651 & 0.376 & 0.606 & 0.439 & 0.380 & $\mathbf{0 . 8 6 6}$ & \\
\hline SV & 0.599 & 0.518 & 0.533 & 0.598 & 0.627 & 0.589 & 0.446 & $\mathbf{0 . 8 9 8}$ \\
\hline
\end{tabular}

Note: Diagonals (in bold) represent square root of the AVE

Table 3: Model's Path Coefficient

\begin{tabular}{|c|c|c|c|c|c|}
\hline $\begin{array}{l}\text { Dependent } \\
\text { Construct }\end{array}$ & $\begin{array}{l}\text { Independent } \\
\text { Constructs }\end{array}$ & Path Coefficient $(\beta)$ & $\begin{array}{l}\text { Observed T- } \\
\text { statistics (t) }\end{array}$ & $\begin{array}{l}\text { Significance Level } \\
\text { (p) }\end{array}$ & Support \\
\hline $\mathbf{R I}$ & $\begin{array}{l}<-A T R \\
<-C S \\
<-G P V\end{array}$ & $\begin{array}{l}0.222^{* * *} \\
0.343^{* * *} \\
0.238^{* * *}\end{array}$ & $\begin{array}{l}3.026 \\
4.543 \\
3.359\end{array}$ & $\begin{array}{l}0.003 \\
0.000 \\
0.000\end{array}$ & $\begin{array}{l}\text { Yes } \\
\text { Yes } \\
\text { Yes }\end{array}$ \\
\hline ATR & $\begin{array}{l}<-H C \\
<-E V \\
<-P K \\
<-S V \\
<-C S\end{array}$ & $\begin{array}{c}0.118 \\
0.159^{* * *} \\
0.140^{* *} \\
0.166^{* * *} \\
0.371^{* * *}\end{array}$ & $\begin{array}{l}1.556 \\
3.474 \\
2.553 \\
2.932 \\
5.607\end{array}$ & $\begin{array}{l}0.120 \\
0.001 \\
0.011 \\
0.003 \\
0.000\end{array}$ & $\begin{array}{l}\text { No } \\
\text { Yes } \\
\text { Yes } \\
\text { Yes } \\
\text { Yes }\end{array}$ \\
\hline CS & $<-G P V$ & $0.669^{* * *}$ & 18.200 & 0.000 & Yes \\
\hline
\end{tabular}

\subsection{Structural Model}

In PLS, the predictive realism level of the model was estimate throughout the $R^{2}$ value that reinforce the model's trustworthy value. The outcome of the model is high index, which explain the high validity of the subsidiary factors based on independent variables. The result of the model is be able to explain following as $50.1 \%$ of the variance in Repurchase intention (RI), green perceived value (GPV) explains $44.7 \%$ of the variance in customer satisfaction (CS), and $57.7 \%$ the variance in attitude (AT) is formatted by health consciousness, environmental concern, product knowledge, safe value, and customer satisfaction. Moreover, due to the $R^{2}$ values of the model are only average, the study analyzed the predictive relevance $\left(Q^{2}\right)$ factor to be more certain about the suitability of the model. According to Chin (2010), the $Q^{2}$ values for each variable need to be greater than zero for potential variables. As the result we get in the table below: the $Q^{2}$ values fluctuate from 0.3 to 0.401 which show the underground structures in this model are completely reasonable. In summary, the model exhibited an acceptable fit and high predictive relevance.

PLS use the nonparametric bootstrapping proposed by Davision and Hinkley (2013) to calculate the significant coefficient. After the bootstrapping process, t-values were calculated to see if whether the coefficient are considerably different from zero. According to Hair et al. (2011), the techniques of non-parametric bootstrapping were utilized in every single sign change, 295 cases and 1000 microsamples. The results showed in Table 3, the path coefficients, t-statistics, and p-value for all latent, which are acceptance or rejection of the advance assumption. In the case of antecedents to attitude, environmental concern (EV) $(\beta=0.159, \quad t=3.474, \quad p<0.01)$, product knowledge $(P K)$ $(\beta=0.140, t=2.553, p<0.05)$, safety value (SV) $(\beta=0.166$, $t=2.932, \quad p<0.01)$, customer satisfaction (CS) $\quad(\beta=0.371$, $t=5.607, p<0.01$ ) were optimistic effect to customer's attitude repurchase intention. Therefore, the $\mathrm{H} 2, \mathrm{H} 3, \mathrm{H} 4, \mathrm{H} 5$ are supported. While, the p-value of the path that linking between health consciousness and attitude is greater than 0.05 and T-statistic value smaller than 1.645 , so $\mathrm{H} 1$ is no supported in this model.

In the relationship between variables with repurchase intention, all significant level of attitude (ATR) $(\beta=0.222$, $t=3.026, \quad p<0.01)$, customer satisfaction (CS) $\quad(\beta=0.343$, $\mathrm{t}=4.543, \quad \mathrm{p}<0.01$ ), and green perceived value (GPV) $(\beta=0.238, \quad t=3.359, \quad p<0.01) \quad$ significant impact to the repurchase intention. Therefore, three-path including $\mathrm{H} 6, \mathrm{H} 8$, $\mathrm{H} 9$ are supported in this structural model. Moreover, the hypothesis $\mathrm{H} 7$ between green perceived value and customer satisfaction is also supported due to the value of 
significant level is less than 0.01 , path coefficient equal 0.669 , and T- statistic value satisfy the criteria.

\section{Discussion and Managerial implications}

The study investigated important factors affecting repurchase intention on organic cosmetics. The results show that health consciousness $(\beta=0.118, t=1.556, p<0.12)$ does not affect customers' intention to buy organic cosmetics. It is incompatible with Ghazali et al., (2017) proof of the health-conscious influence of Malaysian attitudes towards buying organic. However, in accordance with Nguyen's (2015), it is evidence that health consciousness does not affect the attitude of Vietnamese customers. Furthermore, we applied questionnaires of Michaelidou \& Hassan, (2008), and Bauer et al., (2013) to conduct surveys. Therefore, the above results have achieved a certain level of confidence. On the other hand, the remaining factors are consistent with the previous results of Ghazali et al., (2017). The sense of environmental protection $(\beta=0.159, t=3.474$, $p<0.01)$, understanding of products $(\beta=0.140, t=2.553$, $p<0.05)$, safety values $(\beta=0.166, t=2.932, p<0.01)$, and customer satisfaction $(\beta=0.371, t=5.607, p<0.01)$ all have positive effect on the attitude of product acquisition. In which satisfaction has the best effect on customer attitudes. Therefore, marketers should promote product quality as well as services quality to increase product consumption.

In addition, green awareness values $(\beta=0.669, t=18.2$, $p<0.01)$ also have positive effect on consumer satisfaction. They were recognized by Lam et al. (2016) on the repurchase intention toward green products. The results also showed that the advance degree attitude for repurchase intention organic cosmetic has been explored to positive impact on re-buying intention of consumer $(\beta=0.222$, $t=3.026, p<0.01)$. These findings were consistent with the previous studies on the intention of acquiring organic or natural personal care product in Malaysia (Ghazali et al., 2017). Furthermore, customer behavior investigated by employing measurement questionnaire of Bansal and Taylor, (2002). Therefore, the positive attitude of customers has a great influence on the intention of acquiring Vietnamese consumers. Based on the empirical evidence, the study also confirmed that the green awareness value $(\beta=0.238$, $t=3.359, \quad p<0.01)$ and customer satisfaction $(\beta=0.343$, $t=4.543, p<0.01$ ) also positively affected the repurchase intention. Moreover, the intention to buy products has been recognized by previous researchers as the effect of customer satisfaction (Patterson \& Spreng, 1997) and green perceived value (Chen \& Chang, 2013). That result is similar to Lam et al. (2016), when they conducted a survey of consumers' intention to buy green products.

In summary, the repurchase intention toward organic cosmetic is most affected by customer satisfaction, followed by green awareness and ultimately the attitude of consumers. Therefore, the manufacturer should focus more on the friendliness of the product in order to increase customer acquisition intent. In order to increase reconsumption, marketers also upgrade perception green value of their products.

\section{Conclusion and Research Limitations}

The study result given that the repurchase intention for organic cosmetic in Vietnam is impacted by attitude, customer satisfaction and green perceived value. It can be concluded that buying attitude has a significant impact on customers repurchase intention. Also, product awareness, environment concern and safety affect the attitude of acquisition. Thereby the manufacturer can set up handbooks or posters to help people define what organic cosmetics are. Moreover, international anti-counterfeiting and organic certification stamps should be emphasized to ensure safety for users and the environment. However, customer satisfaction plays an important role in customers' attitudes and intentions. Therefore marketers need to have suggestions for quality improvement, packaging, services, consulting and customer care department as well as listening to comments from consumers. Managers can open more free skin screening services to customers, free or have a fast delivery policy, as well as make more special treatment products such as acne treatment, anti-aging. Besides that the higher green awareness value, the easier it is to consume organic cosmetics. Therefore manufacturers can use recyclable packaging, or special slogan sentences to increase green awareness of consumers, or organize campaigns to exchange old packaging to receive gifts.

The paper also has some limitation in constitution and survey process. It does not reflect all the factors that may affect the intention of acquiring customers' organic cosmetics, such as value for money, the influence of organic brands or organizations as well as the level of customer trust. So future study can develop more broadly. Moreover, the survey only obtained convenient responses, it will not fully reflect all market segments as well as the desire of Vietnamese consumers. Besides, the researcher only focuses on the people living in the two big cities of Ho Chi Minh City and Hanoi, so the next study can focus more on others area. 


\section{Reference}

Abd Rahman, A., Asrarhaghighi, E., \& Ab Rahman, S. (2015). Consumers and Halal cosmetic products: knowledge, religiosity, attitude and intention. Journal of Islamic Marketing, 6(1), 148-163.

Ahn, T., Ryu, S., \& Han, I. (2004). The impact of the online and offline features on the user acceptance of Internet shopping malls. Electronic Commerce Research and Applications, 3(4), 405-420.

Ajzen. I., \& Fishbein, M. (1980). Understanding Attitudes and Predicting Social Behavior. Englewood Cliffs, NJ: Prentice-Hall.

Anderson, E. W., Fornell, C., \& Lehmann, D. R. (1994). Customer satisfaction, market share, and profitability: Findings from Sweden. The Journal of Marketing, 58(3), 53-66.

Bansal, H. S., \& Taylor, S. F. (2002). Investigating interactive effects in the theory of planned behavior in a service-provider switching context. Psychology \& Marketing, 19(5), 407-425.

Bauer, H. H., Heinrich, D., \& Schäfer, D. B. (2013). The effects of organic labels on global, local, and private brands: More hype than substance? Journal of Business Research, 66(8), 1035-1043.

Becker, M. H., Haefner, D. P., Kasl, S. V., Kirscht, J. P., Maiman, L. A., \& Rosenstock, I. M. (1977). Selected psychosocial models and correlates of individual healthrelated behaviors. Medical Care, 15(5), 27-46.

Beharrell, B., \& MacFie, J. H. (1991). Consumer attitudes to organic foods. British Food Journal, 93(2), 25-30.

Bolton, R. N. (1998). A dynamic model of the duration of the customer's relationship with a continuous service provider: The role of satisfaction. Marketing Science, 17(1), 45-65.

Bredahl, L. (2001). Determinants of consumer attitudes and purchase intentions with regard to genetically modified food-results of a cross-national survey. Journal of Consumer Policy, 24(1), 23-61.

Chan, R. Y., \& Lau, L. B. (2000). Antecedents of green purchases: A survey in China. Journal of Consumer Marketing, 17(4), 338-357.

Chen, Y. S. (2013). Towards green loyalty: Driving from green perceived value, green satisfaction, and green trust. Sustainable Development, 21(5), 294-308.

Chen, Y. S., \& Chang, C. H. (2012). Enhance green purchase intentions: The roles of green perceived value, green perceived risk, and green trust. Management Decision, 50(3), 502-520.

Chiu, C. M., Chang, C. C., Cheng, H. L., \& Fang, Y. H. (2009). Determinants of customer repurchase intention in online shopping. Online Information Review, 33(4), 761784.

Cosmetic \& U.S. Law (2017). Retrieved Septemper 20, 2018, from https://www.fda.gov/Cosmetics/Guidance Regulation/LawsRegulations/ucm2005209.htm

Cosmetics, Body Care Products, and Personal Care Products (April, 2008). Retrieved from September 18, 2018, from https://www.ams.usda.gov/sites/default/files/ media/OrganicCosmeticsFactSheet.pdf

Chryssochoidis, G. (2000). Repercussions of consumer confusion for late introduced differentiated products. European Journal of Marketing, 34(5/6), 705-722.

Cronin, J. J. Jr., \& Taylor, S. A. (1992). Measuring service quality: A reexamination and extension. The Journal of Marketing, 56(3), 55-68.

Cronin, J. J. Jr., Brady, M. K., \& Hult, G. T. M. (2000). Assessing the effects of quality, value, and customer satisfaction on consumer behavioral intentions in service environments. Journal of Retailing, 76(2), 193-218.

Davis, M. M., \& Heineke, J. (1994). Understanding the roles of the customer and the operation for better queue management. International Journal of Operations \& Production Management, 14(5), 21-34.

Davidow, M. (2003). Have you heard the word? The effect of word of mouth on perceived justice, satisfaction and repurchase intentions following complaint handling. J.Consum. Satisfy. Dissatisfied. Complaint Behaviour, 16(3), 67-80.

Dembkowski, S. (1998). The environmental value attitude system model understanding the divergence between stated environmental consciousness and overt consumer behaviour. Eco-Management and Auditing, 5(2), 62-74.

Fornell, C., \& Larcker, D. F. (1981). Evaluating structural equation models with unobservable variables and measurement error. Journal of Marketing Research, 18, 39-50.

Ghazali, E., Soon, P. C., Mutum, D. S., \& Nguyen, B. (2017). Health and cosmetics: Investigating consumers' values for buying organic personal care products. Journal of Retailing and Consumer Services, 39, 154-163.

Gould, S. J. (1988). Consumer attitudes toward health and health care: A differential perspective. Journal of Consumer Affairs, 22(1), 96-118.

Grunert, S. C., \& Juhl, H. J. (1995). Values, environmental attitudes, and buying of organic foods. Journal of Economic Psychology, 16(1), 39-62.

Han, H., \& Kim, Y. (2010). An investigation of green hotel customers' decision formation: Developing an extended model of the theory of planned behavior. International Journal of Hospitality Management, 29(4), 659-668.

Hair, J. F., Ringle, C. M., \& Sarstedt, M. (2013). Partial least squares structural equation modeling: Rigorous 
applications, better results and higher acceptance. Long Range Planning, 46(1-2), 1-12.

Hair Jr, J. F., \& Lukas, B. (2014). Marketing research. Sydney, Australia: McGraw-Hill Education Australia.

Hennig-Thurau, T., \& Klee, A. (1997). The impact of customer satisfaction and relationship quality on customer retention: A critical reassessment and model development. Psychology and Marketing, 14(8), 737-764.

Hill, H., \& Lynchehaun, F. (2002). Organic milk: attitudes and consumption patterns. British Food Journal, 104(7), 526-542.

Johri, L. M., \& Sahasakmontri, K. (1998). Green marketing of cosmetics and toiletries in Thailand. Journal of Consumer Marketing, 15(3), 265-281.

Keh, H. T., \& Sun, J. (2008). The complexities of perceived risk in cross-cultural services marketing. Journal of International Marketing, 16(1), 120-146.

Kim, S., \& Seock, Y. K. (2009). Impacts of health and environmental consciousness on young female consumers' attitude towards and purchase of natural beauty products. International Journal of Consumer Studies, 33(6), 627-638.

Koelemeijer, K., Roest, H., \& Verhallen, T. (1993, May). An integrative framework of perceived service quality and its relations to satisfaction/dissatisfaction, attitude, and repurchase intentions. Paper presented at the 22nd Annual Conference of the European Marketing Agency, Barcelona, Spain(pp.683-699).

Kraft, F. B., \& Goodell, P. W. (1993). Identifying the health conscious consumer. Marketing Health Services, 13(3), 18-25.

Lam, A. Y., Lau, M. M., \& Cheung, R. (2016). Modelling the relationship among green perceived value, green trust, satisfaction, and repurchase intention of green products. Contemporary Management Research, 12(1), 47-60.

Lea, E., \& Worsley, T. (2005). Australians' organic food beliefs, demographics and values. British Food Journal, 107(11), 855-869.

Lindeman, M., \& Väänänen, M. (2000). Measurement of ethical food choice motives. Appetite, 34(1), 55-59.

Lockie, S., Lyons, K., Lawrence, G., \& Mummery, K. (2002). Eating 'green': motivations behind organic food consumption in Australia. Sociologia Ruralis, 42(1), 23-40.

Luu, Y. N. (2017). Thị trường mỹ phẩm thiên nhiên: "Nút thắt" nguyên liệu. Retrieved from September 18, 2018, from https://doanhnhansaigon.vn/chuyen-lam-an/thitruong-my-pham-thien-nhien-nut-that-nguyen-lieu1079489.html

Michaelidou, N., \& Hassan, L. M. (2008). The role of health consciousness, food safety concern and ethical identity on attitudes and intentions towards organic food.
International Journal of Consumer Studies, 32(2), 163170.

Mittal, V., Ross, W. T. Jr., \& Baldasare, P. M. (1998). The asymmetric impact of negative and positive attribute-level performance on overall satisfaction and repurchase intentions. The Journal of Marketing, 62(1), 33-47.

Natrue label: requirements to be met by natural and organic cosmetic (2017). Retrieved September 20, 2018, from http://www.natrue.org/fileadmin/natrue/downloads/Criteria _3.7/EN-NATRUE-Label_Requirements_V3_7.pdf

Nash, R., Fieldman, G., Hussey, T., Lévêque, J. L., \& Pineau, P. (2006). Cosmetics: They influence more than Caucasian female facial attractiveness. Journal of Applied Social Psychology, 36(2), 493-504.

Newsom, J. T., McFarland, B. H., Kaplan, M. S., Huguet, N., \& Zani, B. (2005). The health consciousness myth: implications of the near independence of major health behaviors in the North American population. Social Science and Medicine, 60(2), 433-437.

Nguyen, N. H. K. (2014). Evaluating factors that affect young consumers' purchase intention toward organic cosmetics in Ho Chi Minh City (Master thesis). Ho Chi Minh City, Vietnam: International University HCMC.

Nguyen, N. D. P., \& Nguyen, T. D. (2017). The effect of country-of-origin on customer purchase intention: A study of functional products in Vietnam. Journal of Asian Finance, Economics and Business, 4(3), 75-83.

Oliver, R. L. (1980). A cognitive model of the antecedents and consequences of satisfaction decisions. Journal of Marketing Research, 17(4), 460-469.

Oliver R. L. (1996). Satisfaction: A Behavioral Perspective on the Consumer. New York, NY: McGrawHill.

Paksoy, R., Özçalici, A. M., \& Çelikkan, R. A. H. (2014). Modeling attitude towards organic foods: A research on adolescents. Business Management Dynamics, 3(7), 4049.

Patterson, P. G., \& Spreng, R. A. (1997). Modelling the relationship between perceived value, satisfaction and repurchase intentions in a business-to-business, services context: An empirical examination. International Journal of Service Industry Management, 8(5), 414-434.

Prothero, A., \& McDonagh, P. (1992). Producing environmentally acceptable cosmetics? The impact of environmentalism on the United Kingdom cosmetics and toiletries industry. Journal of Marketing Management, 8(2), 147-166.

Pudaruth, S., Juwaheer, T. D., \& Seewoo, Y. D. (2015). Gender-based differences in understanding the purchasing patterns of eco-friendly cosmetics and beauty care products in Mauritius: A study of female customers. Social Responsibility Journal, 11(1), 179-198. 
Sharma, N., \& Patterson, P. G. (2000). Switching costs, alternative attractiveness and experience as moderators of relationship commitment in professional, consumer services. International Journal of Service Industry Management, 11(5), 470-490.

Sivadas, E., \& Baker-Prewitt, J. L. (2000). An examination of the relationship between service quality, customer satisfaction, and store loyalty. International Journal of Retail \& Distribution Management, 28(2), 73-82.

Smith, S., \& Paladino, A. (2010). Eating clean and green? Investigating consumer motivations towards the purchase of organic food. Australian Marketing Journal, 18(2), 93104.

Sun, S. Y., Chang, S. C., \& Huang, K. L. (2016). A Study on the Influencing Factors of Cosmetic Beauty Repurchasing Intention. Joint International Conference on Economics and Management Engineering and International Conference on Economic and Business Management.

Sweeney, J. C., \& Soutar, G. N. (2001). Consumer perceived value: The development of a multiple item scale. Journal of Retailing, 77(2), 203-220.

Tam, J. L. (2004). Customer satisfaction, service quality and perceived value: An integrative model. Journal of Marketing Management, 20(7-8), 897-917.

Tsakiridou, E., Boutsouki, C., Zotos, Y., \& Mattas, K. (2008). Attitudes and behaviour towards organic products: An exploratory study. International Journal of Retail \& Distribution Management, 36(2), 158-175.

Tse, D. K., \& Wilton, P. C. (1988). Models of consumer satisfaction formation: An extension. Journal of Marketing Research, 25(2), 204-212.
Van Loo, E. J., Diem, M. N. H., Pieniak, Z., \& Verbeke, W. (2013). Consumer attitudes, knowledge, and consumption of organic yogurt. Journal of Dairy Science, 96(4), 21182129.

Verhoef, P. C. (2005). Explaining purchases of organic meat by Dutch consumers. European Review of Agricultural Economics, 32(2), 245-267.

Wandel, M., \& Bugge, A. (1997). Environmental concern in consumer evaluation of food quality. Food Quality and Preference, 8(1), 19-26.

Wangwiboolkij, R. (2012). Factors influencing the repurchase intention of Thai female customers toward Korean cosmetics in Bangkok. AU-GSB e-JOURNAL, 5(1), 18-26.

Yadav, R., \& Pathak, G. S. (2016). Young consumers' intention towards buying green products in a developing nation: Extending the theory of planned behavior. Journal of Cleaner Production, 135(1), 732-739.

Yin, S., Wu, L., Du, L., \& Chen, M. (2010). Consumers' purchase intention of organic food in China. Journal of the Science of Food and Agriculture, 90(8), 1361-1367.

Zhuang, W., Cumiskey, K. J., Xiao, Q., \& Alford, B. L. (2010). The impact of perceived value on behavior intention: an empirical study. Journal of Global Business Management, 6(2), 1-7.

Kim, H. Y., \& Chung, J. E. (2011). Consumer purchase intention for organic personal care products. Journal of Consumer Marketing, 28(1), 40-47. 